\title{
Bringing critical literacy into tertiary EFL reading class
}

\author{
Endang Setyaningsih \\ English Education Department, Teacher Training and Education Faculty, Universitas Sebelas Maret, Jalan Ir. Sutami \\ 36 A Surakarta, Central Java, Indonesia.
}

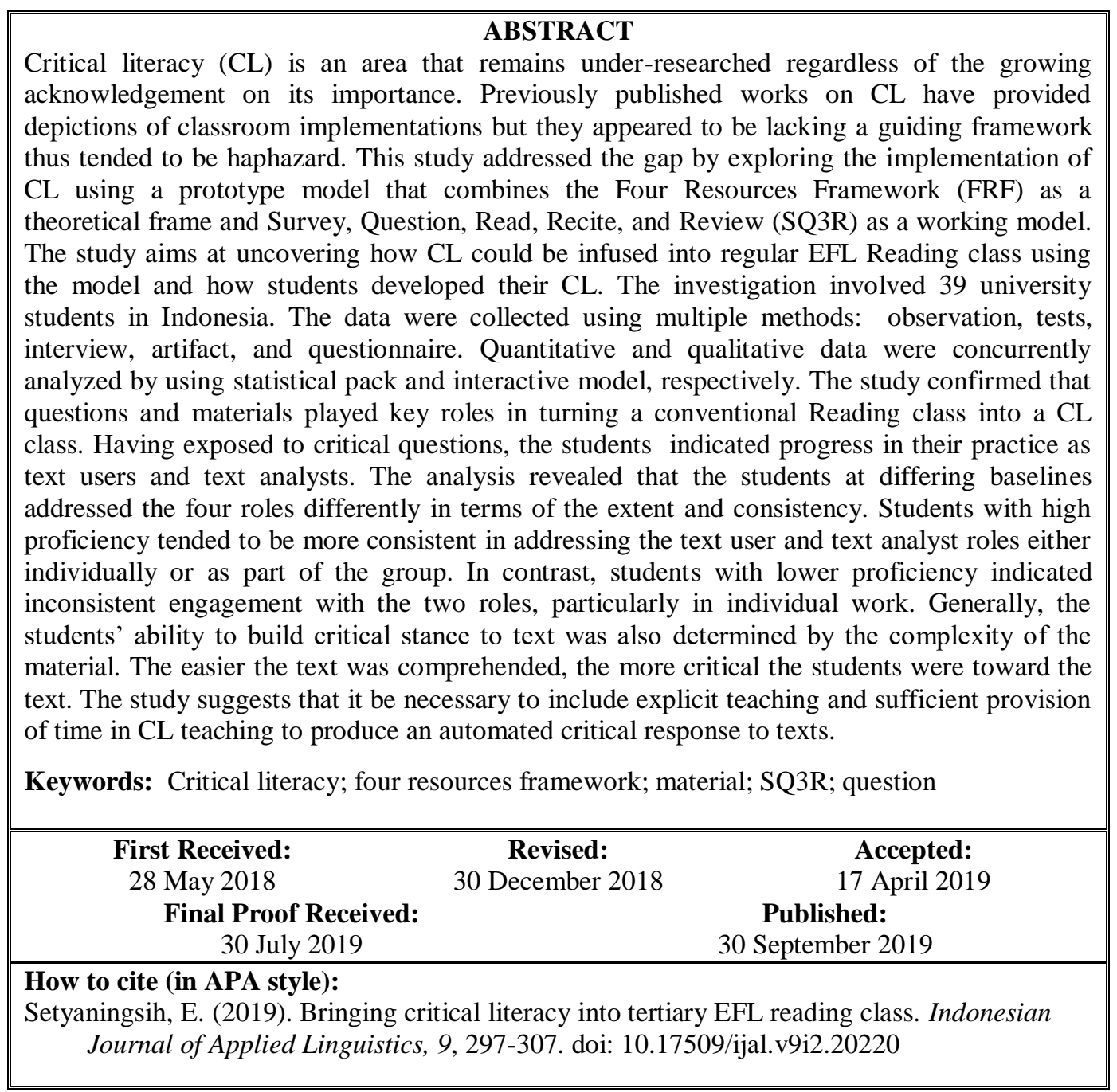

\section{INTRODUCTION}

Reading class has a long tradition of placing texts in a vacuum. It focused on teaching the students the graphic decoding skills as well as strategies to comprehend texts, and the texts tended to be viewed as selfsufficient. (Underwood, Yoo, \& Pearson, 2007). Sociocultural and political aspects are rarely attached as a part of texts and its reading. A text on environmental conservation, for example, was rarely discussed in relation to political interest and policy that surrounded the text production. For this case, with regard to practices of Critical Language Awareness (CLA), Fairclough (1992) criticizes the practice as placing more emphasis on the text as a product than as a process in which text interpretation and production are involved. Common practice in reading class seldom questions the context of the text when it was produced or the social or political identity of the author. Based on the view that texts are crafted (Luke \& Freebody, 1990. For this case it is essential to examine the hidden agenda delivered through the construction and language of the text. Therefore, expanding the notion of reading to include critical reading instead of mere graphic decoding is unarguably a necessity. In fact, along with the rapid spread of texts through the world-wide web, critical reading becomes one of the currencies in today's 
reading research as well as the teaching of reading (Kamil, Pearson, Moje, \& Afflerbach, 2011). An example is seen in the work by Wallace (2003) who presented a case for the social nature of reading. Critical Reading in the context of this study is viewed as one strand in the wider project of Critical Literacy (CL). At CL, students are encouraged to move texts in a questioning way, challenge received knowledge, instead of bringing knowledge passively.

Further, Lankshear (1994) asserted that CL involves, among others, having critical evaluative perspective on particular texts and being able to make critical readings on broader social practices which are mediated, made possible and partially sustained through the reading of texts. In the context of Asia, such conceptions of CL have been brought into EFL/ ESL classroom. Regardless of the existing challenges such as curriculum barrier (Akbari, 2007) and students' proficiency (Park, 2011, Macnish, 2011), the number of studies focusing on the implementation of CL teaching in higher education in Asia gradually proliferated and the result are relatively positive. Taking the setting in a university in Taiwan, Kuo (2014) highlighted the use of picture books in different learning tasks, both individual and in group, focusing on stimulating multiple perspectives. Abednia and Izadinia (2013) demonstrated how university freshmen in Iran engaged in CL. They highlighted students' agency in the CL instruction including negotiating the syllabus by collecting and selecting the passages. This study reveals that the students' engagement in CL were notable from their ability to contextualize issue, problematize issue, define/ re-define key concept, and draw one own or others' experiences. In South Korea, Park (2011) worked with 38 students categorized as having relatively good proficiency in English to find out the instructional steps taken in EFL CL reading classroom, describing how the students engage in critical thinking and identifying the challenges and benefits of building CL in EFL setting. Using the article from New Yorker as material, the teaching and learning process was conducted following phases of pre-whilst-post reading. The study listed three positive results: it produces independent reader, it promotes whole language class, and it motivates students via personal engagement. Language competency and other skills such as leadership, presentation, and collaboration. In addition, sociocultural awareness and agentive development were also noticeable. These studies; however, appeared to be lacking a clear framework in the implementation.

In Indonesia, however, $\mathrm{CL}$ has yet to receive adequate attention regardless of the increasing concern over the students' literacy and critical thinking. The teaching of reading still largely sits on conventional practice, which emphasizes the importance of the attainment of basic comprehension of texts. The activities in a Reading class center at identifying gist, reference, and word meaning. This present study provided a balance between the conventional and critical literacy and the implementation was guided a framework to address the gaps of previous studies.

\section{Critical literacy}

Critical Literacy (CL) is often viewed to be based on several schools, and one of them is postmodernism. Based on the paradigm of postmodernism, the idea of 'standard'; single perspective/ truth that characterized the modern era have produced marginalized people. Robinson (2010) illustrated modern era education as a big factory processing materials (students) per batch in a standardized way, and at the end of the production line, the product (students) undergo quality control (high stake testing). Product (students) who do not meet the standard will be discarded and has no market, thus marginalized. On the other hand, product (students) who meet the standards will be packed in a uniform box of labeled competence.

Critical literacy spotted a gap in this kind of education with real-world demand. Four essential points are forwarded as the basis for changing the educational paradigm: (a) the emerging concern over students literacy, (b) observation on the lifeless democracy, (c) awakening that concepts normally taken for granted by teachers and implicit in their practices (including curriculum) are in fact cultural and 'man'-made, (d) new generations of learners can no longer inherit sociopolitical preconceptions from the past (Cahoon, 1996, Giroux, 1991; Usher \& Edward, 2003; Finch, 2008; Hargreaves, 2005; Weil \& Anderson, 2000). CL concerns on the need to provide education which equips, empowers, and enables students with criticality to resist social unjust, to participate and preserve democracy, to become a fully functioning human being. (Wrigley \& Guth, 1992).

Critical literacy is more than just conventional reading or writing or the combination of the two. CL ushers questioning of social construction as well as one's subjective beliefs and assumption through the use of language in order to make sense of the world and act in it. (Shor, 1999). The 'act' in CL, covers verbal and non-verbal language such as gesture, tattooing, or piercing as indicated in Johnson's study (2011). Meanwhile, from a more practical instructional point of view, CL "transcends conventional notions of reading and writing to incorporate critical thinking, questioning, and transformation of self or one's world." (McDaniel, 2004, p. 474). In the attempt to read the word and the world (Freire \& Macedo, 2005) interpretation shall be placed in context; reading is not conducted in vacuum (Wallace, 2003; Kamil et al., 2011). While to some people questioning status quo may lead to chaos, it is essential to note that $\mathrm{CL}$ values multiple perspectives and thus grows respect to human and humanity by acting for change when change is well-reasoned as necessary.

\section{Conventional and critical literacy framework}

A prominent framework for teaching CL that has been around for nearly three decades is the Four Resources. First introduced as the Four Reader Roles by Luke and 
Freebody in 1990 and later as the 'family of practices' in 1999, the framework gained wide acceptance. To accompany the framework, Luke and his team in MyRead provided several guideposts. Table 1 briefly explains the framework that is adapted in this present study along with the indicators of engagement adapted from the guideposts.

Table 1. The Four Resources Framework (FRF)

\begin{tabular}{|ll|}
\hline Role & Description \\
\hline $\begin{array}{l}\text { Code breaker } \\
\text { (CB) }\end{array}$ & Understanding the symbolic graphic conventions which make up the code. Decoding the codes and \\
& conventions of written and spoken texts.
\end{tabular}

Capstone CB when student accurately derives meaning from text by making sense of written words including specific terms.

Observable e.g. as students read the graphic symbol of written text; attend to the function and use of various categories of words, e.g. parts of speech, synonyms, prefixes; using a range of strategies to support identification of words, e.g. sounds in words, letter patterns, and word meaning; using headings/pictures to predict storyline/ content/ word.

Text participant Understanding literal and figurative meanings within the text. Comprehending written, spoken and visual (TP) texts.

Capstone TP when student continually and accurately derives and infers meanings and analyzing reading with respect to prior knowledge, research, and experience or by making connection: text to self, text to text, text to world. Student indicates full comprehension of the text and probe related points presented in the texts.

Observable e.g. as students construct meaning through the before reading stage; monitoring predictions; linking text ideas to real-life issues; draw on background and prior knowledge to construct meaning; mention/ write the lateral and inferential meaning of the language used in the text; use pictures to predict the text; respond to texts on a personal level i.e. raise follow up questions or probing.

Text user Using the text in social situations to achieve social purposes and participating in events in which the text (TU) plays a part. Understanding the purposes of different written, spoken and visual texts for different cultural and social functions.

Capstone TU when student able to redesign / reconstruct text by making use the understanding of the text in achieving its purpose.

Or when students are able to contextualize the connection made with the text (e.g. participating in genre/ responding to the text).

Observable e.g. as students explore the features of different text types to determine how an author's purpose shapes the way the text is formed; use an understanding of author purpose to determine the main facts and to organize information from the text; draw on a range of sources to synthesize information and express points of view to respond to text (e.g. construct/ design response text or generate new questions); write a meaningful summary or constructing text.

Text analyst $\quad$ Looking for implicit meanings, opinions, and bias, and either endorsing or rejecting the point of view put (TA) forward by the text. Understanding how texts position readers.

Capstone TA when students able to consider written words from various perspectives, track accuracy and reliability, uncover meaning, intentions, agendas, assumption, and priorities, choose important ideas/ thoughts, recognize bias, take a standing toward the text, and provide another ways of doing/writing.

Observable e.g. as students develop a critical response; present reasons to endorse position taken by the text or develops own position; explore how the writer influences reader perceptions; examine the trustworthiness of the information; identify the attitude, point of view, and/ or position of the writer toward the topic.

Developed from Luke and Freebody (1990, 1999), MyRead (Project of the Australian Association for the Teaching of English and the Australian Literacy Educators Association)

Luke and Freebody (1990) posited that the four roles resources are non-developmental nor taxonomic. The roles/resources play a starring role on a different occasion, and they asserted that competent reader is one who recognizes that "on different occasions, different roles or resources occupy the center stage while others play supporting roles from the wings" (Underwood et.al, 2007, p. 92). Underwood exemplified that while code breaker role is involved in any encounter with text, "it occupies center stage when cipher is obscure, or knowledge is weak." (p. 92). This is, nonetheless, subject to further discussion, particularly on what supporting role that the other roles play when one is struggling with phonics decoding. In-depth and comprehensive exploration and observation on the implementation might be required to provide a firm answer. While the FRF has defined the key concepts in CL practice, like any other framework which has to maintain its generalizability, the FRF avoids prescribed staging (Luke \& Freebody, 1990, 1999).

On the other hand, the conventional reading class has been familiar with several models of staged teaching to help students achieved comprehension, and one of them is widely known as the SQ3R. The acronym SQ3R was coined by Robinson in 1941, and it stands for Survey, Question, Read, Recite, and Review; five steps 
of reading/ study skills. Pauk (1999) asserted that this strategy is considered as one that has 'tremendous staying power.' He also reasoned that teachers like to use SQ3R for its concise and clear steps. The 'survey' establishes a purpose for reading the text. In this component the process covers Pre-reading, examination of content, previewing text; surveying headings, pictures, layout, charts, figures, identified words, summaries. The 'question' facilitates active reading and provides a target. In this stage, students constructed questions based on 'survey' to be answered while reading. The 'read' is the stage when students have the first exposure to the full content of a text. The students are to read material with the intent of answering predeveloped questions. The 'recite' aims at organizing and summarizing information. At this stage, students produce verbal and/ or written answer and a summary of what has been read. Finally, the 'review' integrates information in a broader context. At this stage, students re-read the text to solidify understanding and retention. (Carlston, 2011). As one of the classics, the study on SQ3R surprisingly limited and has been in a long paucity. Major research databases recorded only a few studies and one of them is Hubner's meta-analysis (2004). Having analyzed the common themes of the SQ3R studies, Hubner indicated her criticism on the studies and mentioned that SQ3R is prone to effectiveness. For example, while briefly describing the studies on SQ3R and its variations, she noted that some positive claims and results of the strategy might have an unclear basis and reference. Also, Hubner posited concern on the implementation of the strategy and mentioned that frameworks and requirements are needed for the success of implementation. However, she conceded to cite benefit that can be agreed upon, i.e. potential for independent use regardless the weak support for SQ3R effectiveness to help students.

The review of the literature reveals that while previous studies in CL have placed a considerable amount of practical illustration on CL implementation, the CL practices appear to be haphazard and lacking explicit guiding framework. Moreover, considering the context of implementation and the illustrated activities, the studies commonly gave strong emphasis on the critical pole of literacy with a minimum, if not absent, information on the conventional literacy thus tended to be replicable only in the context of CL teaching as a part of the mainstream curriculum. Therefore, the current study addresses the gap by using Luke and Freebody's Four Resources Framework (FRF) as it offers a potential swing from conventional to critical reading. Several studies have suggested that the teaching of CL should not be introduced immediately without the development of traditional skills or sufficient engagement with the text. (Freebody, Ludwig, \& Gunn, 1995; Kuo, 2014). Considering the generic nature of a framework including the FRF, this present study incorporated FRF into a classic Robinson's Survey, Question, Read, Recite and Review (SQ3R) model to allow workable lesson structuring. Unlike previous studies which relied heavily on the qualitative depiction of CL progress, this study presents quantitative measurement as well as qualitative itemization, instead of generalization, of observable indicators that signal students' engagement in the FRF, i.e. students as code-breaker, text participant, text user, and text analyst.

\section{METHOD}

This present study employed a concurrent mixed methods design. The quantitative measure was conducted to satisfy the reading of score-based CL progress in addition to the qualitative description of the CL progress. The participants of this study were 39 first semester students of the English Education Department of a university in Central Java Province, Indonesia. At the Department, there were two reading classes, and each consists of the same number of students. One of the classes is randomly selected as the observed class. The tryout of the Instruments was conducted in the other class. The students in both classes had relatively similar characteristics in terms of heterogeneity of English proficiency, and they both neither had any experience of CL class nor were familiar with the practice of questioning texts.

Based on the institution policy, both Reading classes shared the same syllabus. The syllabus was relatively conventional and covered areas such as finding meaning from context (including identifying meaning of suffixes), identifying main idea, detail information, reference, and text structure/ genre. While there was a long list of expected attitude and general competencies which cover the cognitive, affective, and psychomotor domain, it is the list of specific competencies that become the center of attention. This means that teaching and learning weigh heavily on cognition. For the purpose of this study, the syllabus of the observed class was modified to include CL but at the same time maintaining the original mandatory syllabus. The detail on how the syllabus is modified is reported in the findings.

In practice, a prototype model which combines FRF and SQ3R (Setyaningsih, Lengkanawati, Musthafa, 2019) was applied in one semester. The semester was basically divided into two major parts: the introduction session and the practice sessions. In the introduction sessions, concepts of CL were explicitly taught, and questioning was exemplified by the instructor by using the direct method, i.e. explicit teaching of the CL concepts. In the practice sessions, each selected text was read following the stage of the model, i.e. Surveying, Questioning, Reading, Reciting, and Reviewing. To operationalize the model, description, and activities in each of the stages were presented in students' worksheets. The students were encouraged to construct their own questions at any stage of the model whenever possible. At this second part, the students worked cooperatively using the Learning Together Model (Johnson \& Johnson, 2001). The students were grouped 
into three to five students, and each student was assigned a certain role. In group of three, the roles include resource person, encourager/ timer, and note taker/ summarizer. In group of 5, two students shared similar roles as resource person and note taker/ summarizer. This role assignment is a way to foster individual accountability. In addition, students were called randomly to report their discussion. This means that everyone in the group had to know the material. Each member worked together to accomplish the task, i.e. filling out the SQ3R worksheet, and this made the positive interdependence. At the end of the group work, students reported the result of their discussion and evaluated their cooperation in the group processing sheet.

Guided by the research questions, this study employed multiple methods of data collections and analysis. This mixed method design was rarely found in previous studies of CL. Earlier works on CL implementation commonly heavily weighed on qualitative exploration or description, and this study attempted to fill the methodological gap. The employment of mixed methods was based on two reasons: first, to achieve a fuller understanding of the students' engagement in CL and second, to verify findings obtained from both quantitative method and qualitative method. In answering the first research question, a pair of tests was carried out, and the results were analyzed quantitatively to obtain general map of students' progress. This quantitative method, however, tended to ignore the context of data; thus, could not give a complete understanding of the target phenomenon, i.e. students' CL development. Therefore, qualitative method was also employed to understand and explore the process and the context and to highlight and explain contradictions and peculiarities. Dornyei (2007) and Creswell (2009) pointed out that the mixed method bridges the traditional quantitative and qualitative method. Mixing both methods also permitted dialogue between the quantitative and qualitative data; thus, permitted justification of findings. In addition, comparing findings from multiple methods allowed display of contradiction and peculiarities; thus, permitted clarification of findings in a nested context. In this study, the quantitative and qualitative data collection occurred in one phase that lasted for one semester, which fell into the category of a concurrent mixed method (Creswell, 2009).

The quantitative data obtained from tests and questionnaire were statistically described and tested. The scores of tests, in particular, were calculated using the Wilcoxon signed rank test. Wilcoxon was chosen over paired t-test because the students' scores were not in a normal distribution. Based on Hatch and Lazaraton (1991), when the normality assumption was not fulfilled by the data, Wilcoxon should be opted instead of paired t-test.

At the same time, qualitative data obtained from observation (field notes), students' artifacts, interrview, and questionnaire were analyzed by using Miles and
Huberman (1994) interactive model. The interactive model is characterized as having major phases that include data reduction, data display, and conclusion drawing/ verification. At the initial stage, all data from students' artifacts, field notes, and interviewwere collected. After a moment of data immersion, the data were compared with and coded based on the guidepost or rubric. At this stage, the data were reduced as the irrelevant ones were excluded. Next, the coded data were categorized based on their similarities and recurrence. This coding allows the data to be more manageable and displayable. Recurrent theme or categories were interpreted to allow a conclusion. All these stages are interactive, which means that it is possible to return to a particular stage, including the data collection stage when it is considered necessary. The findings were then discussed by highlighting the findings of previous studies and/or other concepts.

\section{FINDINGS AND DISCUSSION \\ Infusion of $\mathrm{CL}$ into conventional reading class}

The original syllabus of the Reading class consists of three competencies: general competencies, specific competencies, and personal/ social competencies. General competencies and attitude cover items such as: being responsible, becoming an active citizen, being able to cooperate, having social sensitivity, applying critical, logical, systematic, and innovative thinking, etc. Meanwhile, the specific competence includes the following five: finding meaning from context, identifying main idea, identifying detailed information, recognizing the reference, and text structure. This specific competence turns out to be the sole attention as reflected in the lesson plan and in particular in the activity and the targeted learning experience. The teaching method suggested for the class was cooperative learning in addition to lecturing. The reading strategy was not specified. In framing the original syllabi within the FRF, several adjustments, mainly specification, were made.

Reflecting on previous studies on CL implementation, the selection of material was one of the crucial elements in the infusion. Three considerations for selecting material in this study were: (1) complexity of texts (including length), (2) variation of genre, (3) stimulating/ provoking topics. The texts used in this study varied in terms of length, but all were under two pages long. To ensure its readability, the texts were measured with the aid of Coh-Metrix. In general, the selected texts were expected to sit at a point that allowed the development of both traditional comprehension skills and critical literacy. The degree of complexity increased as the sessions progressed. At the early sessions the selected texts were the shortest and simplest ones. This was to allow students at low proficiency level to have a sense of success and invited a larger number of students to get in touch to critical questions immediately. The texts used in this study covered various genres and forms: printed advertisements (air pollution by Coca Cola company 
and Greenpeace), a campaign video on gender equity (Do It Together), a satire text (Fresh Air will Kill You by Art Buchwald), A short text (Momentous Arrest by Martin Luther Jr, A Feminist Double Standard), Posters (on stereotyping), a news article (Time Magazine is in Hot Water over a Tweet on Amal Clooney's Baby Bump published in Huffington Post), a poem (I too by Langston Hughes), and an online article (Students Bullying Teacher). It was transparent from the titles that the topics of the texts had the potential to trigger the students' critical perspectives. Morover, this study opted for topics which were close to students' life. When students found the material relatable to them (in terms of experiences and views), they would be both affectively and cognitively engaged with the text. Basic comprehension was also facilitated because there was an interaction between the reader's background knowledge and the text as explained by schema theory (Carrel \& Eisterhold, 1983).

The importance of material selection echoed the previous study by Kuo (2014) and Abednia and Izadinia (2013) who achieved positive results, partly due to the suitable materials, and study by Park (2011) that faced challenges due to the selection of material with less familiar topic and language above the students' level. The students' proficiency has been an area that remains under debate when it comes to CL teaching. While Ko (2013) concluded that CL should be taught to students with high English proficiency, Wallace (2003) mentioned that criticality does not root at proficiency. Luke and Freebody (1999) also mentioned the nondevelopmental characteristics of the reader roles which implies that critical stance can be built at any level of proficiency. This study took a compromise by facilitating students' comprehension through the teaching of traditional reading skills while at the same time endorsing a critical approach to texts. Admittedly, the study confirmed that there was a certain threshold level that the students needed to pass before they could make a critical approach.

Regardless of the heterogeneity of the students' proficiency levels, opting for differentiated materials for different category of students as in Shen's study (2009) is arguably less ideal for CL for at least three reasons. First, it did not allow open discussion since each group had access to different texts. Second, such a situation created marginalization in the class that CL fight against. Third, practically, planning different material for each category is highly demanding in terms of time and thinking, including the consequence of preparing differentiated teaching scenario. Then, the materials for the study were not differentiated to meet different categories of students. The choice of materials of the study had largely anticipated problems identified in previous CL studies. The instruction process, mainly in the second part of the semester, followed the prototype model, as presented in Table 2.

In addition to the carefully selected material, questions played a major role in this infusion. At the first part of the semester, the students were explicitly taught on CL and were introduced to the concept of thin and thick or critical questions. The students were involved in a critical dialogue which stimulated their thinking on hidden motive or agenda. Also, the students did several activities that introduced them to the idea of multiple perspectives and stereotyping. These were conducted through

- stereotype worksheet (students matched a word and the stereotype commonly attached to the words, and continuing a sentence based on the students commonly held belief),

- switching activities (changing the gender and setting of a story to get different perspectives)

- Kuo's (2014) colored glass activity (students look at the same thing through different colored lenses and disscuss their differences)

- blind-folded description activities (being blindfolded the students describe an object based on the part that they first touch)

This explicit introduction made the concept of CL clear for the students as later indicated in their constructed questions and response to a text. This confirms the previous study by Kuo (2014) who also highlighted an explicit introduction of CL as an element of success in the CL teaching. In contrast, Huang (2011) who did not provide the explicit introduction to $\mathrm{CL}$ concepts found that the students cannot directly refer to critical stance when conceptualizing reading. Although the students were able to practice text analyst role during the study, it is likely that the students will cease being critical outside the class

Table 2 also shows that the CL teaching moves in a continuum from conventional to the critical pole but always allow texts to be approached critically at any points. This arrangement is based on the belief that the students' critical engagement to texts should be based on a good comprehension of the texts. (Huh, 2016; Park, 2011; Kuo, 2014). In this study, it becomes apparent in the students' critical responses to text that were off target. The students, who as text participant, failed to answer a fundamental question on the gist of the text also practiced text analyst role when prompted with a question on the author's agenda. Nonetheless, the critical attempt made by the students was then baseless. In a nutshell, the infusion of critical literacy into the conventional reading class was made by balancing the two poles of literacy. However, students' timeline in achieving the balance differs one to another. This implies that the implementation of the model may require further adaption to address the issue of heterogeneity of the students.

\section{Students' critical literacy development}

The participants of this study took two tests: pre and post-test (see Table 3). There was an interval of 11 weeks between the two tests in which CL instruction took place. The initial number of pre-test takers was 39 , but the number of post-test takers decreased to 35 students. The absentees did not withdraw from the study 
but decided not to take/ re-take the tests due to the tight schedule they had. These differences were taken with care. Data presentation and statistical calculation were sensitive to the changing number of participants. A statistical calculation to indicate students' progress was then carried out by using the non-parametric measure Wilcoxon Signed Rank test in statistical pack 2.4. The test was chosen because the data failed to meet the normal distribution assumption as indicated in Figure 1 and Figure 2.

Table 2. The Critical Literacy (CL) infusion: Four Resources Framework (FRF) and the SQ3R

\begin{tabular}{|c|c|c|c|c|}
\hline Component & FRF & & Process & Task \\
\hline \multirow[t]{4}{*}{ Survey } & Code breaker & : & $\begin{array}{l}\text { Examining words, charts, picture, layout, } \\
\text { headings. }\end{array}$ & $\begin{array}{l}\text { Predicting content from the one-minute } \\
\text { survey }\end{array}$ \\
\hline & Text participant & $:$ & $\begin{array}{l}\text { Understanding the message obtained from } \\
\text { previewing by reflecting background knowledge/ } \\
\text { stored information, relate to other text, to self, to } \\
\text { world }\end{array}$ & $\begin{array}{l}\text { Skimming text for gist and to identify } \\
\text { major feature of a text. } \\
\text { Activating background knowledge on the } \\
\text { topic. }\end{array}$ \\
\hline & Text user & : & $\begin{array}{l}\text { Recognize/ identify headings, lay out/ } \\
\text { organization and its effect. }\end{array}$ & $\begin{array}{l}\text { Researching the context of the text and } \\
\text { who is behind the text. }\end{array}$ \\
\hline & Text analyst & : & $\begin{array}{l}\text { Questioning the motive right from the beginning, } \\
\text { identify stereotype that might be addressed and } \\
\text { predict if it will be maintained or challenged. }\end{array}$ & Predicting the author's motive \\
\hline
\end{tabular}

\begin{tabular}{lllll}
\hline Questions & Code breaker & $:$ & Questioning choice of words, the meaning of & Constructing five thin questions \\
& & words/ terms used & Constructing five thick/ critical questions
\end{tabular}
information, questions relation to previously stored knowledge, questions example/ non example.

Text user $\quad$ : questioning purpose and how it is achieved through text structuring, question the style/ language used for delivering the purpose

Text analyst : Questioning what/who is addressed and what is not addressed, question the motive/ intention/ attitude, question text genetics, question the impact and consequences of the text

\begin{tabular}{|c|c|c|c|c|}
\hline Read & $\begin{array}{l}\text { Engage in RFR } \\
\text { simultaneously } \\
\text { as reading } \\
\text { proceed }\end{array}$ & : & $\begin{array}{l}\text { First engaging, intense exposure to the full content } \\
\text { of text. Getting answer to previously asked } \\
\text { questions and construct questions from the text: } \\
\text { questions which are answered by the section read } \\
\text { and critical questions that emerge during reading. }\end{array}$ & $\begin{array}{l}\text { Reading the text carefully } \\
\text { Writing down emerging questions in the } \\
\text { margin } \\
\text { Marking answers to pre-developed } \\
\text { questions }\end{array}$ \\
\hline Recite & $\begin{array}{l}\text { Code breaker } \\
\text { Text participant }\end{array}$ & 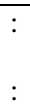 & $\begin{array}{l}\text { Producing a verbal and/ or written answer on } \\
\text { questions related to code breaking } \\
\text { Producing a verbal and/ or written answer/ }\end{array}$ & $\begin{array}{l}\text { Producing spoken and/or written answers } \\
\text { of pre-developed questions. } \\
\text { Paraphrasing }\end{array}$ \\
\hline
\end{tabular}
summary to show understanding of the content of the text, e.g. main ideas and detail information Text user : Producinng a verbal and/ or written text response (e.g., reply, poster, summary) using the learned structure and or modify the learned structure to achieve the intended goal.

Text analyst : Producing a verbal and/ or written answer on text analyst questions; state/ write/ challenge recognition of intention/motive, stereotype, unjust positioning, silenced/echoed point of view.

\begin{tabular}{ll} 
Review $\quad$ Code breaker & $: \begin{array}{l}\text { Solidifying the meta-knowledge/ strategy and } \\
\text { engagement in the code breaker role. }\end{array}$ \\
Text participant & $: \begin{array}{l}\text { Solidifying the meta-knowledge and engagement } \\
\text { in comprehending the text and make a relation of } \\
\text { the information obtained in a broader social } \\
\text { political ideological context. } \\
\text { Text user }\end{array}$ \\
Text analyst & $\begin{array}{l}\text { Solidifying the meta-knowledge and engagement } \\
\text { in recognizing text purpose and structure, and } \\
\text { show the ability to use the text for the intended } \\
\text { purpose. } \\
\text { Solidifying the meta-knowledge and engagement } \\
\text { in text analyst; show/ do/ come up with ideas to } \\
\text { act for change. }\end{array}$ \\
\hline
\end{tabular}

Writing one-two paragraphs of summary

Constructing follow up questions and/ or provide a response to a text through switching activities (i.e., switching the perspectives, gender, setting)

\begin{abstract}
Writing an appraisal critical review, contesting the text to alternate perspectives (connecting/ contrasting/ comparing text to other texts/ previous readings) and stating standing as well as planning action.
\end{abstract}

Responding to a text review

Developed based on Robinson (1941), Pauk (1984, 1994), Carlston (2011), Luke and Freebody (1990, 1999), Setyaningsih et al., (2019)

With the rejection of null hypothesis, it means that there is a significant difference in students' critical literacy before and after the instruction.
To obtain clearer picture on the performance of the students within each which aspect of the FRF and how they improved, average score of each aspect in the pre- 
test was compared to that in the post-test. The development of each role was visualized in Figure 3.

Table 3. Description of Students' Pre- and Post-Test Scores

\begin{tabular}{|c|c|c|c|c|c|}
\hline & $\mathbf{N}$ & Min. & Max. & Mean & Std. Dev. \\
\hline Pre & 35 & 10 & 22 & 14.71 & 2.444 \\
\hline Post & 35 & 10 & 24 & 16.37 & 3.742 \\
\hline $\begin{array}{l}\text { Valid N } \\
\text { (listwise) }\end{array}$ & 35 & & & & \\
\hline
\end{tabular}

The study also reveals that the students, though at diverging level of proficiency, indicated similar pattern of engagement in CL practice within the FRF.

The indices in Table 4 were addressed by all students. Nevertheless, observation and students artifacts revealed that the extent of engagement differs across students with different level of proficiency and across mode of tasks. Students with a lower level of proficiency were still at the stage of struggling for gaining basic comprehension. This means that the text participant role occupied the center stage (Underwood et al., 2007). This brings up threshold issue into discussion. The students who did not gain basic comprehension of texts generally either did not attempt to make critical stance or fail to make on point critical stance. As exemplified in the students' review papers, the attempt to uncover the author's agenda was not on target due to incomprehension of the texts. This finding thus confirms previous studies conducted by Kuo (2014), Ko (2013), and Huh (2016).

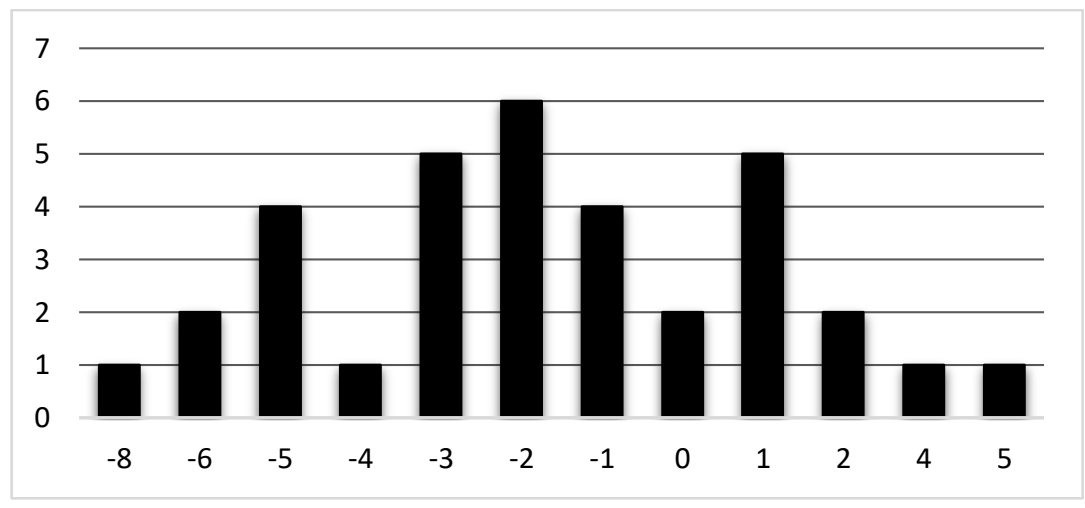

Figure 1. D distribution of Pre and Post-Test

\begin{tabular}{|c|c|c|c|c|}
\hline & Null Hypothesis & Test & Sig. & Decision \\
\hline 1 & $\begin{array}{l}\text { The median of differences betwee } \\
\text { Pre and post equals } 0 \text {. }\end{array}$ & $\begin{array}{l}\text { Related- } \\
\text { Samples } \\
\text { Q Wuilcoxon } \\
\text { Signed Rank } \\
\text { Test }\end{array}$ & .015 & $\begin{array}{l}\text { Reject the } \\
\text { null } \\
\text { hypothesis. }\end{array}$ \\
\hline
\end{tabular}

Asymptotic significances are displayed. The significance level is 05 .

Figure 2. Hypothesis Test Summary: Wilcoxon Signed Rank Test

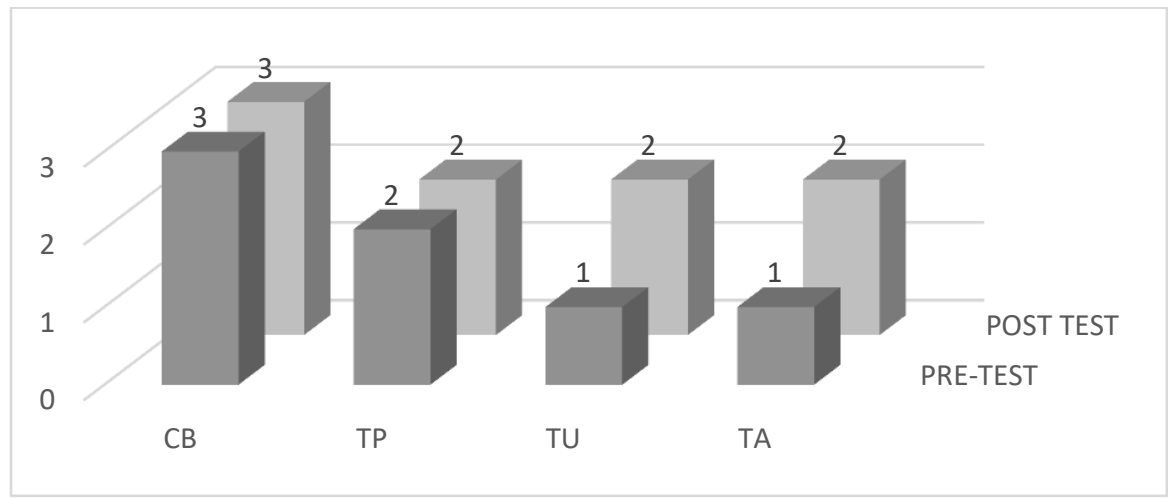

Figure 3. Development of FRF components 
Table 4. Indication of engagement in the Four Resources Framework

\begin{tabular}{|c|c|c|c|}
\hline Code breaker & Text participant & Text user & Text analyst \\
\hline $\begin{array}{l}\text { reading the graphic symbols } \\
\text { of written words, and }\end{array}$ & $\begin{array}{l}\text { constructing meaning through } \\
\text { before reading stage, }\end{array}$ & writing meaningful summary. & $\begin{array}{l}\text { Examine the trustworthiness } \\
\text { of the information, and }\end{array}$ \\
\hline \multirow[t]{6}{*}{$\begin{array}{l}\text { using heading/ pictures to } \\
\text { predict storyline/ content }\end{array}$} & $\begin{array}{l}\text { providing relation to other } \\
\text { texts, }\end{array}$ & $\begin{array}{l}\text { synthesizing information and } \\
\text { expressing various point of } \\
\text { views to respond to text, }\end{array}$ & $\begin{array}{l}\text { Identifies intention/ motives, } \\
\text { the attitude, point of view and } \\
\text { position toward the text }\end{array}$ \\
\hline & $\begin{array}{l}\text { differentiating sample and } \\
\text { non-sample, }\end{array}$ & $\begin{array}{l}\text { understanding of author } \\
\text { purpose to determine the main } \\
\text { fact and to organize } \\
\text { information from the text, and }\end{array}$ & \\
\hline & monitoring prediction, & $\begin{array}{l}\text { determining how the author } \\
\text { purpose shapes the way the } \\
\text { text is formed }\end{array}$ & \\
\hline & $\begin{array}{l}\text { linking text to real life issues } \\
\text { and background knowledge, }\end{array}$ & & \\
\hline & $\begin{array}{l}\text { constructing probing } \\
\text { questions, and }\end{array}$ & & \\
\hline & $\begin{array}{l}\text { understanding the lateral and } \\
\text { inferential meaning of } \\
\text { language, and general and } \\
\text { specific ideas of the text }\end{array}$ & & \\
\hline
\end{tabular}

Apart from the linguistic problem, the students with lower proficiency level also tended to require more prompts in their engagement. After the explicit teaching at the introductory sessions, the proportion of instructor's question decreased as the course progressed and the students were encouraged to create their own thin and thick questions and made a reflection/ review of texts based on the questions. However, the students with lower proficiency level were unable to independently question text and maintain their critical stance when prompting questions were absent. Referring to Skill Acquisition Theory (DeKeyser\& Criado, 2013), this finding can be interpreted that the students' CL practice had not reached an automated level of skill. The explicit teaching of CL and exposure to CL-related topics were sufficient to bring the students some sort of declarative knowledge. As Bowker (2010) would point out, "expecting students to instantly produce thoughtful answer was naïve and it was even more naïve to expect them produce powerful questions." It took time for the students to take part in critical literacy. More, the findings signify what Cotton (1998) said to be the function of question, i.e. to cue, stimulate, and direct students to the elements to be learned or to what students have to do and how to do it. Likewise, Orlich, Harder, Callahan, and Gibson, (1998), and Degener and Berne (2016) noted that the produced responses depended on how the questions were framed. In this study, it was transparent in the students' answer to the prompting questions. After gaining basic comprehension on the text content, the students, who had no prior experience to approach text critically, were able to respond to questions that directed them to practice text user and text analyst role, for example, identifying the agenda of the author and who was benefitted by the text. At a time when students cannot understand a certain text, questions still fully function to direct the students into the target role. However, in a case like this, the students' responses were relatively misleading or unacceptable because they were based on a misunderstanding or incomprehension of the content of texts. Still, the students practiced text user and text analyst role.

This study also revealed that a dedicated introductory session played an essential part in the attainment of the study's positive result. Previous studies by Ko (2013) and Kuo (2014), for example, denoted comparable encouraging result. Both Ko and Kuo devoted the first session for CL introduction. In Ko's, the teacher used the story of six blind men and an elephant to introduce multiple perspectives in CL. Meanwhile, Kuo used colored glass activity which was then adopted for CL introduction in this study. On the contrary, a study by Huang (2011) which had no session for introducing $\mathrm{CL}$, concluded with a concern that the students might cease being critical outside the class. The concern was based on the finding that students knew and were able to practice text analysis but could not directly refer to critical stance when conceptualizing reading. It is unlikely that CL would be maintained if the students had not changed their view on reading. This study, however, indicated contrast findings. The students were able to re-conceptualize their reading as a part of CL. However, some students indicated on and off engagement in the text analyst role. They required prompts to build critical stance to the text, and when prompts were absent, the students' engagement commonly rests as text participant. This means that the 
students had the knowledge on critical approach to reading, but the action to approach text is not yet critically at the level of automation.

\section{CONCLUSION}

The study concludes that incorporating CL into a conventional class is possible and doable through modification of the existing syllabus. The prototype model that combined the FRF and SQ3R provides a balanced approach to CL. Using the model, the students at diverging baselines indicated a similar pattern of engagement in CL, but they differed in terms of the extent of the engagement. Generally speaking, the application of the model supported the development of students' CL under several cautions. First, explicit teaching on CL has to be made at the introductory session. Second, the material should be carefully selected in terms of topic familiarity and language complexity. As denoted in this study, while the critical stance can be built at any stage, comprehension threshold is an issue that needs to be taken up. Third, time allotment and practices should be sufficient to allow habituation of mind. The students at lower level proficiency indicated inconsistent engagement in the CL and this suggests that the habit of questioning texts has not been automated. The connection between proficiency and CL, however, is beyond the scope of this present study.

\section{REFERENCES}

Abednia, A., \& Izadinia, M. (2013) Critical pedagogy in ELT classroom: Exploring contributions of critical literacy to learners' critical consciousness. Language Awareness, 22(4), 338-352. doi: 10.1080/09658416.2012.733400.

Akbari, R. (2007). Transforming lives: Introducing critical pedagogy into ELT classrooms. ELT Journal, 62 (3), 276-283. doi: 10.1093/elt/ccn025.

Bowker, M., H. (2010). Teaching students to ask questions instead of answering them. Thought \& Action, 127-134.

Bui, T. (2016). Critical literacy in an EFL classroom in Vietnam: Agentive empowerment, ideological and language transformations. The Journal of AsiaTEFL, 13(4), 247-261, doi: 10.18823/asiatefl.2016.13.4.1.247.

Cahoon, L. (1996). From modern to postmodernism: An anthology. Massachusetts: Blackwell publishing.

Carlston, D. L. (2011). Benefits of student-generated note packets: A preliminary investigation of SQ3R implementation. Teaching of Psychology, 38(3) 142-146. doi: 10.1177/0098628311411786.

Carrel, P.L., \& Eisterhold. J.C. (1983). Schema theory and ESL reading pedagogy. TESOL Quarterly, 17(4), 553-573.

Cotton, K. (1988). Classroom questioning. School Improvement Research Series. Available at
http://educationnorthwest.org/sites/default/files/Cl assroomQuestioning.pdf

Creswell. (2009). Research design: Qualitative, quantitative, and mixed method approaches. California, CA: SAGE Publication Inc

Degener, S., \& Berne, J. (2016). Complex questions promote complex thinking. The Reading Teacher. 70(5), 595-599, doi: 10.1002/trtr.1535.

Dekeyser, R. \& Criado, R. (2013). Automatization, skill acquisition, and practice in second language acquisition. In C.A. Chapel. (ed) The encyclopedia of applied linguistics. New Jersey: Blackwell Publishing.

Dornyei, Z. (2007). Research methods in applied linguistics: quantitative, qualitative, and mixed method methodologies. Oxford: Oxford University Press

Eastman, L. (1998). “Oral discussion in teaching critical literacy to beginners. In A. Burns \& S. Hoods (Eds), Teachers voices 3: Teaching critical literacy. Sydney: NCELTR

Fairclough, N. (Ed). (1992). Critical language awareness. London: Longman

Finch, A. E. (2008). Postmoderinsm in TEFL: An overview. Retrieved on September 1, 2015 from www.researchgate.net/publication/237629373

Freebody, P., Ludwig, C., \& Gunn, S. (1995). Everyday literacy practices in and out of schools in low socioeconomic urban communities. Brisbane: Centre for Literacy Education Research, Griffith University.

Freire, P. \& Macedo, D. (2005). Literacy reading the word and the world. South Hadley, MA: Bergin \& Garvey.

Giroux, H. A. (1991). Towards a postmodern pedagogy. In Cahoon, L. (Eds). From modern to postmodernism: An anthology. Massachusetts: Blackwell publishing

Hargreaves, A. (1994). Changing teachers, changing times: Teachers' work and culture in the postmodern age. Teacher Development. London: Cassell.

Hatch, E.M. \& Lazaraton, A. (1991). The research manual: Design and statistics for applied linguistics. New York: Newbury House.

Huang, S.Y. (2011). Reading further and beyond the text: Student perspectives of critical literacy in EFL reading and writing. Journal of Adolescent \& Adult Literacy, 55(2), 145-154. doi: 10.1002/JAAL.00017.

Hubner, J. (2004). A Closer Look at SQ3R. Accessed April 20, 2017. Available at https://docs.google.com/viewer?a=v\&pid=sites\&sr cid=ZGVmYXVsdGRvbWFpbnxzY2hvb2x0ZXdz fGd4OjY2OTgzOTYwYTEzODhmZA

Huh, S. (2016). Instructional model of critical literacy in an EFL context: Balancing conventional and critical literacy. Critical Inquiry in Language Studies. 13(3), 210-235. doi:10.1080/15427587.2016.1154445. 
Janks, H. (2013). Critical literacy in teaching and research. Education Inquiry, 4(2), 225-242. doi: 10.3402/edui.v4i2.22071

Johnson, E. (2011). I've got swag': Simone performs critical literacy in a high-school English classroom." English Teaching, 10(3), 26.

Johnson, R.T. \& Johnson, D.W. (2001). An overview of cooperative learning. Available at http://digsys.upc.es/ed/general/Gasteiz/docs_ac/Jo hnson_Overview_of_Cooperative_Learning.pdf

Kamil, M.L., Pearson, P.D., Moje, E.B., \& Afflerbach, P.P. (2011). Handbook of reading research: Volume IV. New York: Routledge

Ko, M.Y. (2013). Critical literacy practices in the EFL context and the English language proficiency: Further exploration. English Language Teaching, 6(11), 17-28. doi: 10.5539/elt.v6n11p17

Kuo, J.M. (2014). Critical literacy in the EFL classroom: Evolving multiple perspective through learning tasks. The Journal of ASIA TEFL. 11(4), 109-138.

Lankshear, C. (1994). Critical literacy (Occasional Paper No. 3). Belconnen, Australian Capital Territory: Australian Curriculum Studies Association.

Luke, A. \& Freebody, P. (1990). 'Literacies' programs: Debates and demands in cultural context. Prospect, 5(3), 7-16.

Luke, A. \& Freebody, P. (1999). Further notes on the four resources model. Reading Online. Retrieved from http://www.readingonline.org/past/past_index.asp? $\mathrm{HREF}=/$ research/lukefreebody.html

McDaniel, C. (2004). A questioning stance and the possibility for change. The Reading Teacher, 57 (5), 472-481.

Macknish, C. J. (2011). Understanding critical reading in an ESL class in Singapore. TESOL Journal, 2(4), 444-472. doi: 10.5054/tj.2011.269747.

Miles, M.B and Huberman, M.A. (1994). Qualitative data analysis: An expanded sourcebook. California: SAGE

MyRead. (2002). Four resources guideposts. Available at http://www.myread.org/monitoring_guideposts.htm
Orlich, D.C., Harder, R.J., Callahan, R.C., \& Gibson, H.W. (1998). Teaching strategies: A guide to better instruction (5th edn.). Boston: Houghton Mifflin Company

Park, Y. (2011). Using news articles to build a critical literacy classroom in an EFL setting. TESOL Journal, 2(1), 24-51. doi: 10.5054/tj.2011.244134.

Robinson, F.P. (1941). Diagnostic and remedial techniques for effective study. New York: Harper and Bros.

Robinson, K. (2010). Changing education paradigm. (video animation). London: Cognitive Media.

Setyaningsih. E., Lengkanawati, N.S., \& Musthafa, B. (2019). Developing a teaching model for critical literacy infusion into conventional reading class: Framing SQ3R within the four resources framework. Second Conference on Language, Literature, Education, and Culture (ICOLLITE 2018) (pp. 296-299). Atlantis Press. doi: 10.2991/icollite-18.2019.65

Shor, I. (1999). What is Critical Literacy? Journal of Pedagogy, Pluralism, and Practice, 1(4), 1-32

Underwood, T., Yoo, M.S., \& Pearson, P.D. (2007). Understanding reading comprehension in secondary schools through the lens of the four resources model. in L.S. Rush, A.J. Eakle, A. Berger (Eds.), Secondary school literacy: What research reveals for classroom practice (pp. 90116). Urbana IL: National Council of Teachers of English.

Usher, R. \& Edwards, R. (2003). Postmodern and education: Different voices, different worlds. London: Routledge

Wallace, C. (2003). Critical reading in language education. NY: Palgrave Macmillan

Weil, D. \& Anderson, K. (2000). Perspectives in critical thinking: Essays by teachers in theory and practice. New York: Peter Lang Publishing

Wrigley, H.S. \& Guth, G.J.A. (1992). Bringing literacy to life: Issues and options in adult ESL Literacy. Aguiire International, San Mateo: California for the U.S. Department of Education Office of Vocational and Adult Education. 